\title{
Biomimetic Strontium Substituted Calcium Phosphate Coating for Bone Regeneration
}

\author{
Marcella Torres Maia ${ }^{1}\left(\mathbb{D}\right.$, Ana Lorena de Brito Soares ${ }^{1} \mathbb{D}$, Matheus Afio Caetano ${ }^{1}$, Fábia Karine Andrade ${ }^{1}$, \\ Enrique Rodríguez-Castellón ${ }^{2, *}$ and Rodrigo Silveira Vieira ${ }^{1, *}$ \\ 1 Department of Chemical Engineering, Federal University of Ceará, Fortaleza 60455-760, Brazil; \\ marcellatmaia@gmail.com (M.T.M.); lorena.soares@gpsa.ufc.br (A.L.d.B.S.); \\ matheusafio@icloud.com (M.A.C.); fabiakarine@gmail.com (F.K.A.) \\ 2 Department of Inorganic Chemistry, Crystallography and Mineralogy, University of Málaga, \\ 29016 Málaga, Spain \\ * Correspondence: castellon@uma.es (E.R.-C.); rodrigo@gpsa.ufc.br (R.S.V.); Tel.: +34-645263909 (E.R.-C.); \\ $+55-85986962919$ (R.S.V.)
}

Citation: Maia, M.T.; Soares, A.L.d.B.; Caetano, M.A.; Andrade, F.K.; Rodríguez-Castellón, E.; Vieira, R.S. Biomimetic Strontium Substituted Calcium Phosphate Coating for Bone Regeneration. Coatings 2021, 11, 908. https://doi.org/10.3390/coatings 11080908

Received: 5 July 2021

Accepted: 26 July 2021

Published: 29 July 2021

Publisher's Note: MDPI stays neutral with regard to jurisdictional claims in published maps and institutional affiliations.

Copyright: (c) 2021 by the authors. Licensee MDPI, Basel, Switzerland. This article is an open access article distributed under the terms and conditions of the Creative Commons Attribution (CC BY) license (https:// creativecommons.org/licenses/by/ $4.0 /)$.

\begin{abstract}
Cellulose acetate (CA)/strontium phosphate ( $\mathrm{SrP}$ ) hybrid coating has been proposed as an effective strategy to build up novel bone-like structures for bone healing since CA is soluble in most organic solvents. Strontium $\left(\mathrm{Sr}^{2+}\right)$ has been reported as a potential agent to treat degenerative bone diseases due to its osteopromotive and antibacterial effects. Herein, bioactive hybrid composite SrP-based coatings (CASrP) were successfully produced for the first time. CASrP was synthesized via a modified biomimetic method (for $7-\mathrm{CA} 7 \mathrm{dSrP}$, and 14 days-CA14dSrP), in which the metal ion $\mathrm{Sr}^{2+}$ was used in place of $\mathrm{Ca}^{2+}$ in the simulated body fluid. Energy-dispersive X-ray (EDX) and Fourier transform infrared spectroscopy (FTIR) analysis confirmed the SrP incorporation chemically in the CASrP samples. Atomic absorption spectroscopy (AAS) supported EDX data, showing $\mathrm{Sr}^{2+}$ adsorption into $\mathrm{CA}$, and its significant increase with the augmentation of time of treatment (ca. $92 \%-\mathrm{CA} 7 \mathrm{dSrP}$ and $96 \%-\mathrm{CA} 14 \mathrm{dSrP}$ ). An increment in coating porosity and the formation of SrP crystals were evidenced by scanning electron microscopy (SEM) images. X-ray diffraction (XRD) evidenced a greater crystallinity than CA membranes and a destabilization of CA14dSrP structure compared to CA7dSrP. The composites were extremely biocompatible for fibroblast and osteoblast cells. Cell viability (\%) was higher either for CA7dSrP (48 h: ca. 92\% and 115\%) and CA14dSrP (48 h: ca. $88 \%$ and $107 \%$ ) compared to CA ( 48 h: ca. $70 \%$ and $51 \%$ ) due to SrP formation and $\mathrm{Sr}^{2+}$ presence in its optimal dose in the culture media $\left(4.6-9 \mathrm{mg} \cdot \mathrm{L}^{-1}\right)$. In conclusion, the findings elucidated here evidence the remarkable potential of CA7dSrP and CA14dSrP as bioactive coatings on the development of implant devices for inducing bone regeneration.
\end{abstract}

Keywords: bone-implant interface; adverse effects; biopolymers; biomineralization; hydroxyapatite derivatives

\section{Introduction}

Bone fractures have been treated mainly by bone grafting; however, their effectiveness remains not well understood [1]. Bone tissue engineering is a promising approach to develop bioceramic implants for bone healing [2]. Bone is mainly composed of HA nanocrystals along collagenous fibers comprising around $90 \%$, while other biomolecules (non-collagenous proteins, proteoglycans, and lipids), 10\% [3,4]. Based on this hybrid composition, materials formed by inorganic and organic phases have been synthesized, like scaffolds, to mimic the natural bone structure [5]. These scaffolds must attend to biological functions by the successful design for guided bone regeneration (GBR) [6]. The hybrid composites (two phases) exhibit superior mechanical and biological properties compared to the single phases. The organic phase increases flexibility, biodegradability, biocompatibility, and reduces compaction, while the inorganic, in addition to the non-toxicity, favors 
mechanical resistance, thermal stability, and induces osteo-promotion [7]. This synergistic combination in forming coatings for implants produces intermediary materials that may contribute to attachment, differentiation, and proliferation of selective cell population and avoid an inappropriate tissue reaction, contributing to bone repair $[8,9]$.

Cellulose is the most abundant natural polymer found in plants (constituting their cell walls) and is extracted mainly through the wood. Its non-toxicity, lower cost, and tailorability make it an interesting alternative to synthetic polymers $[10,11]$. Cellulose-based composites have been widely applied for drug-delivery systems [12], tissue engineering [13], wastewater treatment [14,15], textiles, and sensors [16]. Cellulose comprises a close-packed structure constituted by microfibrils interacting through intra- and intermolecular hydrogen bonds between its molecules and polymeric chains. The occurrence of hydroxyl groups on the surface of this well-known polymer results in high crystallinity, liquid-absorbing ability, suitable compressive stiffness, and tensile strength [15].

As a consequence, a low solubility represents a current drawback to be overcome [17]. $\mathrm{CA}$, in contrast, is a derivative of cellulose that is soluble in polar aprotic organic solvents with acetyl groups at the surface, reducing the formation of hydrogen bonds and structure compaction, which increases its degradation rate. The hydrophilic behavior, easiness to degrade, and biocompatibility are important for avoiding long-term inflammation and surgery to remove the implant [15] and for a controlled release of active molecules and bone tissue repairment (from weeks to years) $[11,13,18]$.

Due to the natural origin of CA, cost-effectiveness, moderate flux (as a membrane), non-toxicity, biodegradability, mechanical, and relative inertness, this biopolymer has several applications in films, textiles, cigarette filters, bioseparation, biomolecule immobilization, bone tissue engineering, and surgical products [19-22]. In the context of boneimplant applications, CA is an outstanding material for coating development [23] since unlike cellulose, it not has shown to cause loss of osteogenic activity [24], but using it as the only component is insufficient to induce osteointegration and confer suitable mechanical and physicochemical properties [25-27]. Therefore, CA has been combined with other constituents to improve its applicability, like collagen [13], $\alpha$-tri-calcium phosphate $(\alpha-\mathrm{TCP})[26]$, HA [7,28], iron [19], boron [29], gelatin [29], pullulan [27], graphene [30], and chitosan [23]. HA is a calcium phosphate compound $\left(\mathrm{Ca}_{10}\left(\mathrm{PO}_{4}\right)_{6}(\mathrm{OH})_{2}\right)$ commonly associated with polymeric matrices to constitute the inorganic counterpart of hybrid scaffolds to improve their osteoinductive properties [31,32]. HA and HA derivatives such as calcium phosphate salts [9] have been used to confer such relevant features for bone repair simulation in close conditions to those observed in the human body.

Immersion in a simulated body fluid (SBF) is a common and straightforward procedure to deposit a calcium phosphate layer on biomaterials [33] and, recently, metal ions have also been incorporated into this inorganic component [34-36]. Strontium $\left(\mathrm{Sr}^{2+}\right)$ is like calcium $\left(\mathrm{Ca}^{2+}\right)$ with a close atomic radius, equal valence, and common biochemical metabolic routes. The great interest in $\mathrm{Sr}^{2+}$ also comes from its dual action, which enables one to favor bone formation and avoid bone resorption [37]. Complementary studies have evidenced that $\mathrm{Sr}^{2+}$ shows anti-bacterial behavior [38], working out over the low occlusiveness of the material, preventing infection and implant failure $[39,40]$. This metal ion has already been used as the active component in a strontium ranelate (SrRan) drug to treat osteoporosis that usually appears in postmenopausal women [41]. The biological effect of $\mathrm{Sr}^{2+}$ was shown to be dose-dependent $[42,43]$. $\mathrm{Sr}^{2+}$ has been incorporated into $\mathrm{HA}$ by ion exchange with $\mathrm{Ca}^{2+}$ or directly in the synthesis process in which $\mathrm{Sr}^{2+}$ is used instead of $\mathrm{Ca}^{2+}$, producing $\mathrm{Sr}^{2+}$ substituted HA (SrHA) [36,44-47].

In this sense, a few works related to $\mathrm{Sr}^{2+}$ such as adding it to a metal's surface [48,49], bioactive glasses $[38,39,50]$, or substituting $\mathrm{Ca}^{2+}$ in HA [42,46] on bacterial cellulose [35,36], poly(L-lactic acid) [32,51], and chitosan/silk fibroin [52] have been published [53]. However, to our knowledge, none of them explored the potential of CA as a framework in combination with $\mathrm{SrP}$ to produce coatings. We aimed to synthesize a bioactive hybrid composite SrP-based coatings (CASrP) by an adapted biomimetic method and unveil 
the biological effects of $\mathrm{SrP}$, analyzing their suitability to the further development of implantable devices for bone repair. The coating porosity and $\mathrm{Sr}^{2+}$ substitution in $\mathrm{CaP}$, which is important for cell ingrowth and proliferation, were proven by morphological, structural, and physicochemical analysis. The $\mathrm{Sr}^{2+}$ release, bioactivity, and cytotoxicity enabled us to investigate their cellular response.

\section{Materials and Methods}

\subsection{Materials}

$\mathrm{CA}(\mathrm{Mw}=30,000 \mathrm{~g} / \mathrm{mol})$ was obtained from Sigma-Aldrich (St. Louis, MO, USA). Acetone (analytical reagent) was obtained from Neon (São Paulo, SP, Brazil). Dulbecco's modified Eagle medium (DMEM) high glucose, Minimum Essential Medium $\alpha$ ( $\alpha$-MEM), $10 \%$ fetal bovine serum (FBS), and antibiotics were obtained from Gibco ${ }^{\circledR}$ Cell Culture (Grand Island, NY, USA). Ultrapure water (type 1) was obtained from a Milli- ${ }^{\circledR}$ Direct Water Purification System (EMD Millipore, Burlington, MA, USA).

\subsection{Methods}

\subsubsection{Synthesis of SrP on CA}

For CASrP production, initially, a $\%\left(\mathrm{w} \cdot \mathrm{v}^{-1}\right)$ CA solution was prepared by dissolving CA powder in $100 \mathrm{~mL}$ acetone. Then, to facilitate the dissolution and homogenate completely, it was kept under the agitation of $500 \mathrm{rpm}$ for $1 \mathrm{~h}$ (Drehzahl electronic, IKAMAG REO, Staufen, Germany) and sonicated for $30 \mathrm{~min}$ in an ultrasonic bath (Unique, USC 1450, Indaiatuba, SP, Brazil). Next, the final solution was verted in Petri dishes to allow acetone evaporation at room temperature for about $30 \mathrm{~min}$, followed by rinsing with distilled water to interrupt the evaporation process. Finally, the membrane was washed with distilled water and stored. Then, to incorporate the $\mathrm{Sr}^{2+}$ substituted hydroxyapatite, the biomimetic mineralized CASrP were fabricated as follows: (1) m-SBF solution (an equal mixture of solution A: $6.213 \mathrm{~g} \cdot \mathrm{L}^{-1} \mathrm{NaCl}, 5.948 \mathrm{~g} \cdot \mathrm{L}^{-1} \mathrm{NaKHCO}_{3}, 0.450 \mathrm{~g} \cdot \mathrm{L}^{-1} \mathrm{KCl}$, $0.462 \mathrm{~g} \cdot \mathrm{L}^{-1} \mathrm{~K}_{2} \mathrm{HPO}_{4} \cdot 3 \mathrm{H}_{2} \mathrm{O}, 0.622 \mathrm{~g} \cdot \mathrm{L}^{-1} \mathrm{MgCl}_{2} \cdot 6 \mathrm{H}_{2} \mathrm{O}$, and $0.144 \mathrm{~g} \cdot \mathrm{L}^{-1} \mathrm{Na}_{2} \mathrm{SO}_{4}$; with solution $\mathrm{B}: 6.213 \mathrm{~g} \cdot \mathrm{L}^{-1} \mathrm{NaCl}$ and $0.584 \mathrm{~g} \cdot \mathrm{L}^{-1} \mathrm{SrCl}_{2}$ ) was prepared based on a modified Bohner and Lemaître method [54], and (2) after that, the membranes of CA were immersed in $\mathrm{m}$-SBF solution under stirring at $\mathrm{pH} 7.4$ and temperature of $36.5^{\circ} \mathrm{C}$ for 7 and 14 days using a Dubnoff shaking water bath (Quimis, Q226M, Diadema, SP, Brazil). Then, the CA7dSrP and $\mathrm{CA} 14 \mathrm{dSrP}$ membranes were obtained, washed with distilled water, and freeze-dried.

\subsubsection{Scanning Electron Microscopy (SEM)}

The samples were covered with a thin layer of gold $(10 \mathrm{~nm})$ using a sputter coater (K650, Emitech, Lorraine, France) and observed using a scanning electron microscope DSM 940 model (accelerating voltage $15 \mathrm{kV}$, Zeiss, Jena, Germany).

\subsubsection{X-ray Diffraction (XRD)}

XRD patterns were obtained using an Xpert Pro MPD (40 kV, 40 mA, PANalytical, Almelo, The Netherlands) with a scanning scope of $10^{\circ}-60^{\circ}$, step size of $0.02^{\circ}$, and scanning speed of $0.5^{\circ} \mathrm{min}^{-1}$ using $\mathrm{Cu} \mathrm{K} \alpha$ radiation $\left(\lambda=1.5406 \times 10^{-10} \mathrm{~m}\right)$.

\subsubsection{Fourier Transform Infrared Spectroscopy (FTIR)}

FTIR analyses were performed using the potassium bromide (KBR) method in a spectrophotometer (Perkin Elmer, Waltham, MA, USA) with a resolution of $4 \mathrm{~cm}^{-1}$ and 48 scans, and a reading range of $4000-400 \mathrm{~cm}^{-1}$.

\subsubsection{Bioactivity}

To evaluate the potential of the CA to favor apatite formation during the synthesis of CASrP, the liquid absorbing capacity of CA was analyzed in SBF and m-SBF. The CA samples were maintained in the media during a fixed time interval $(0,2,4,6,8,10,20,30$, and $40 \mathrm{~min}$ ) at $25^{\circ} \mathrm{C}$. The excess of liquid was removed with a filter paper (Quanty, $8 \mu \mathrm{m}$ ) 
and the swollen material was weighed at the established times. The measurements were performed in triplicate. The swelling degree was calculated according to Equation (1):

$$
D_{s}=\frac{W_{s}-W_{d}}{W_{d}}
$$

where $D_{s}$ is the ratio of liquid-absorbing capacity; $W_{s}$ is the wet weight sample; and $W_{d}$ is the dry weight sample.

In addition, to verify whether the biomimetic methodology employed induced apatite nucleation, energy-dispersive $\mathrm{x}$-ray, operating at higher electron voltage $(\mathrm{eV})$, provided elemental mapping to determine the presence of Sr and P elements in CA7dSrP and CA14dSrP.

\subsubsection{In Vitro Degradability Test}

The CA, CA7dSrP, and CA14dSrP samples were cut into cubes of $10 \mathrm{~mm} \times 10 \mathrm{~mm}$ and weighed, followed by immersion in a $50 \mathrm{~mL}$ centrifuge tube containing $10 \mathrm{~mL}$ of phosphate-buffered saline (PBS), and incubated in a bath at $37^{\circ} \mathrm{C}$ for 60 days under an agitated condition. After each incubation period, the sample was rinsed with distilled water and freeze-dried. The dry weights were measured. The percentual of degradation was calculated following Equation (2):

$$
\text { Weight remaining }(\%)=\frac{W_{i}-W_{f}}{W_{i}} \times 100
$$

where $W_{i}$ corresponds to the initial weight and $W_{f}$ refers to the final weight.

\subsection{7. $\mathrm{Sr}^{2+}$ Release}

Atomic absorption spectroscopy (AAS) was used to determine the $\mathrm{Sr}^{2+}$ concentration in the culture media after exposure to the medium alone in the indirect method according to the International Organization for Standardization (ISO 10993-12). The amount of Sr released from the samples was quantified using a calibration curve for standards of known concentrations of $\mathrm{Sr}\left(0,0.5,1,3,5,7,10\right.$, and $\left.20 \mathrm{mg} \cdot \mathrm{L}^{-1}\right)$. The AAS measurements were performed in duplicate for each system. The cell culture medium was used as the control sample.

\subsubsection{Cell Cytotoxicity}

The cytotoxicity of the materials was evaluated through an indirect method, in which cell viability is measured after exposure to the sample extracts. To prepare the extracts, initially, the samples were cut into cubes $10 \mathrm{~mm} \times 10 \mathrm{~mm}$ and sterilized by autoclaving at $121^{\circ} \mathrm{C}$ for $20 \mathrm{~min}$. Then, samples of each material were aseptically placed in a 24-well plate with $1 \mathrm{~mL}$ of the supplemented DMEM or $\alpha$-MEM culture medium supplemented with $10 \% \mathrm{FBS}$ and $1 \%$ penicillin-streptomycin and incubated at $37^{\circ} \mathrm{C}$ for $24 \mathrm{~h}$ according to ISO 10993-5:2009. After the incubation period, the extracts were collected for the assay.

L-929 cells (mouse fibroblasts) were seeded in supplemented DMEM medium and MC3T3-E1 (mouse osteoblasts) in supplemented $\alpha$-MEM culture medium at a density of $6 \times 10^{3}$ cells / well into the 96-well polystyrene plate, followed by incubation at $37^{\circ} \mathrm{C}(5 \%$ $\mathrm{CO}_{2}$ and $95 \%$ of humidity) for $24 \mathrm{~h}$. After that, the culture medium was removed from the wells and $100 \mu \mathrm{L}$ of the sample extract was added to each well and the plate was again incubated at $37^{\circ} \mathrm{C}$ for 24 and $48 \mathrm{~h}$. After this period, the extract was removed from the wells and $120 \mu \mathrm{L}$ of supplemented culture medium containing the resazurin reagent (final concentration of $25 \mathrm{mg} \cdot \mathrm{L}^{-1}$ ) was added. The plate was incubated for $4 \mathrm{~h}$ under standard culture conditions, then $100 \mu \mathrm{L}$ of the medium containing the metabolized resazurin was transferred to a new 96-well plate and the absorbance was measured in a microplate reader (SpectraMax i3x, Molecular Device, Sunnyvale, CA, USA) in fluorescence mode $\left(\lambda_{\text {excitation }}=560 \mathrm{~nm}\right.$ e $\left.\lambda_{\text {emission }}=590 \mathrm{~nm}\right)$. The positive control was performed by exposing 
the cells to dimethylsulfoxide at $40 \%$ (diluted in the corresponding supplemented culture medium), highly toxic to the cells. The negative control group was performed by exposing the cells only to the corresponding supplemented culture medium. The viability of the cells of the negative control group was adjusted to $100 \%$ for the calculation of mean values and standard deviation $(n=5)$. The cell viability was calculated following Equation (3):

$$
V_{c}(\%)=\frac{F_{S}}{F_{C}} \times 100
$$

where $V_{c}$ represents the percentual of living cells; $F_{S}$ corresponds to the intensity of the fluorescence of cultivated cells exposed to the extract of the sample; and $F_{C}$ refers to the intensity of the fluorescence of cultivated cells in the presence of the culture media.

\section{Results and Discussion}

\subsection{Membrane Characterization}

\subsubsection{SEM}

Several approaches have been performed to improve scaffold properties for bone repair. A porous structure is essential to mass transfer such as oxygen, nutrients, growth factors, waste products, and bone cell ingrowth. To simulate the extracellular matrix of the natural bone and support the bone formation, the CA polymer was chosen for this work due to its superior degradation capacity, natural origin, and non-toxicity compared to other cellulose derivatives. CA membranes were synthesized using phase inversion by immersion precipitation to obtain porous 3D structures [55] easily.

Initially, CA was wholly dissolved in acetone and placed in a Petri dish so that the volatile solvent started to evaporate, forming a membrane and detaching from the plate. After $30 \mathrm{~min}$, the polymer was rinsed with distilled water and the exchange between the solvent and non-solvent caused the precipitation and formation of pores during membrane synthesis. Since drying and precipitation are processes not entirely controlled, the inversion method produces heterogeneous membranes. Figure $1(\mathrm{a} 1, \mathrm{a} 2)$ shows that the CA membrane exhibited a smooth, porous, and non-uniform arrangement [56].

To mimic the inorganic phase of mineralized bone, SrP was incorporated through the biomimetic method, and to improve osteogenesis properties, $\mathrm{Sr}^{2+}$ was used in place of $\mathrm{Ca}^{2+}$. In Figure 1(b1,b2), after immersion in the m-SBF solution for seven days to nucleate SrP into $\mathrm{CA}(\mathrm{CA} 7 \mathrm{dSrP})$, the membrane exhibited a more significant number of pores and a decrease in pore size compared to CA. The increased permeability due to higher porosity contributed to the delivery of $\mathrm{Sr}^{2+}$ metal ions, favoring bone formation. In addition, different patterns of crystal growth were evidenced in the CA-based scaffolds.

The hybrid material CA14dSrP displayed a superior $\mathrm{Sr}^{2+}$ amount trapped into the matrix, inducing a homogeneous interaction between the sites of this metal ion and phosphate in the media during the treatment with $\mathrm{m}-\mathrm{SBF}$. Increased nucleation sites were imparted on forming SrP crystals (see Figure 1(c1,c2)) [33,42,43]. Spherical-like SrHA particles can be seen covering the CA membrane and the pores in the layer considered for SEM appeared to have been filled by SrP. As a result, the pores were not well determined. 


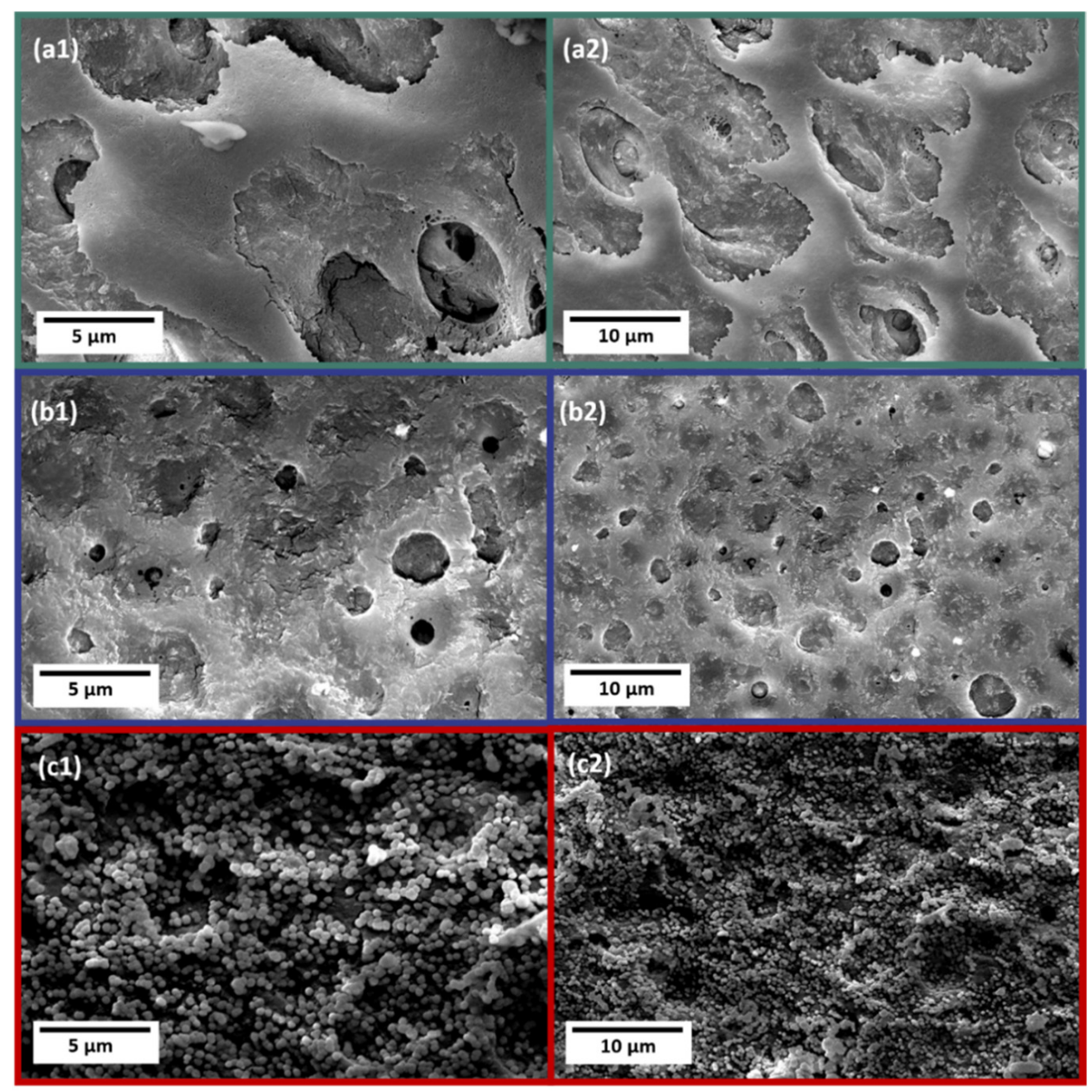

Figure 1. Scanning electron microscopy images of surfaces of cellulose acetate (CA) (a1,a2), CA7dSrP (b1,b2), and CA14dSrP (c1,c2).

\subsubsection{XRD}

X-ray diffractograms of CA, CA7dSrP, and CA14dSrP are shown in Figure 2. The results display differences in the crystallinity of CA after the incorporation of SrP. The semi-crystalline structure was verified by the broader characteristic peak of CA around $2 \theta=20^{\circ}$. Since the measurement was performed in a range from $10^{\circ}$ to $85^{\circ}$, the peak at $2 \theta=9^{\circ}$ observed by [57] was not evident. However, an elevation may be seen at the beginning of the graph in Figure $2 \mathrm{a}$. CA7dSrP, on the other hand, besides the peak of CA at $20^{\circ}$ was less intense; peaks corresponding to $2 \theta=29.5^{\circ}, 32.3^{\circ}, 37.2^{\circ}, 42.5^{\circ}$, and $53.3^{\circ}$ are also presented in Figure $2 b$. These peaks were observed by [36], referring to SrP. Like CA7dSrP, XRD patterns were obtained for CA14dSrP; however, at $29.5^{\circ}, 37.2^{\circ}$, and $42.5^{\circ}$ less intense peaks were shown as well as an increase in the intensity of the $53^{\circ}$ peak, as can be seen in Figure 2c. Other peaks appeared at about $66.5^{\circ}$ and $78^{\circ}$. Even though the rise of new peaks could indicate an increase in crystallinity, the intensity of some of them was reduced in CA14dSrP (see Figure 2c). A longer time in contact with the solution of $\mathrm{m}-\mathrm{SBF}$ containing $\mathrm{Sr}^{2+}$ may have improved the absorption of this metal ion by the CA matrix because of the large radius of this metal ion $(0.118 \mathrm{~nm})$ [41]. Previously, it was shown that with the augmentation of $\mathrm{Sr}^{2+}$ content, broader peaks were observed in XRD. Likewise, in the bacterial cellulose structure, Luz et al. mentioned that a destabilization and enhancement of its solubility [36] occurred following [58]. Consequently, after the formation of SrP into CA, the presence of new peaks resulted in an improved structural organization (as shown previously in Figure 1(c1,c2)) and thus crystallinity. A superior time of CA in contact with the m-SBF solution contributed to the SrP nucleation and growth, and the increased amount of $\mathrm{Sr}^{2+}$ adsorbed into the membrane. 


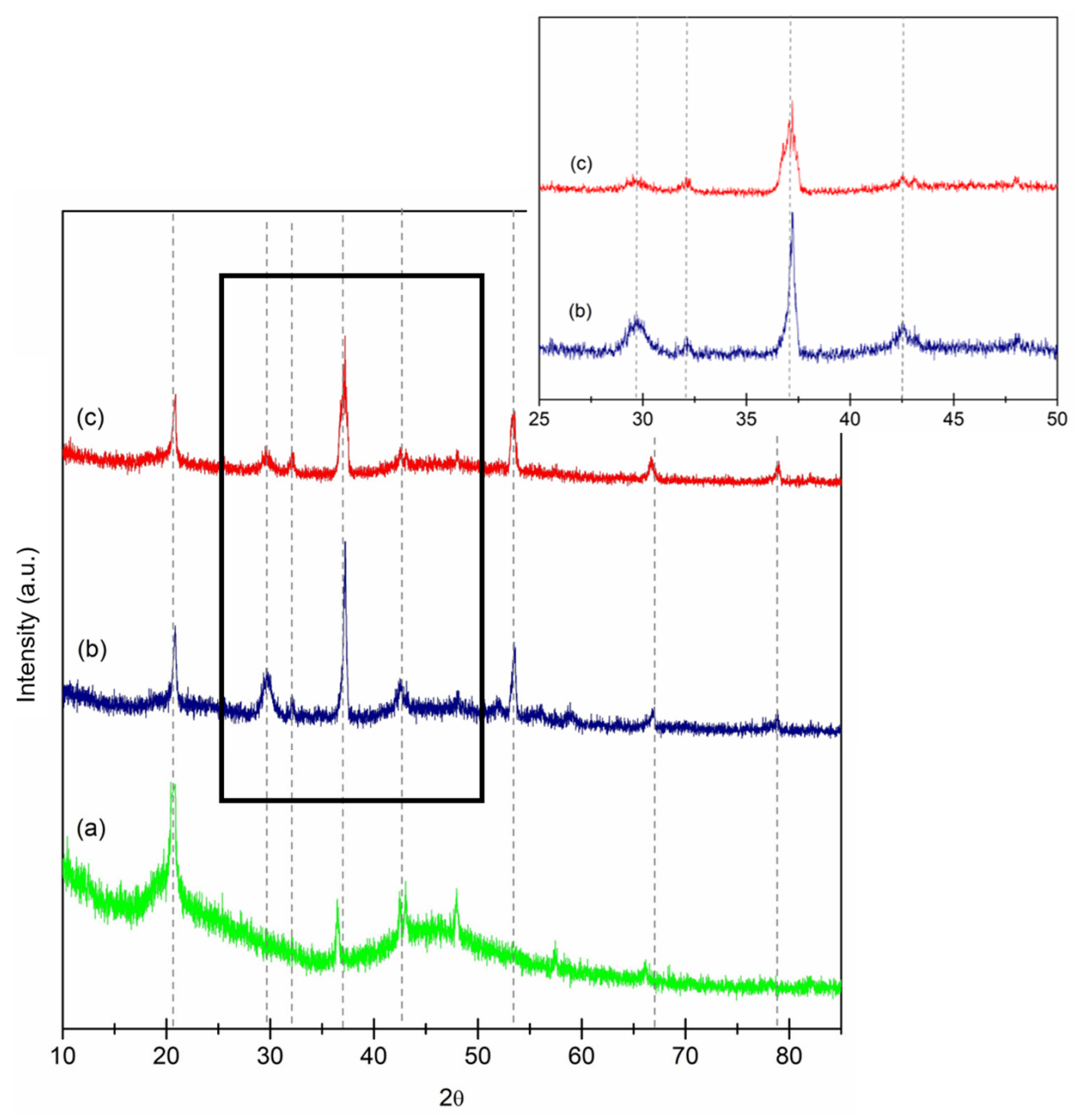

Figure 2. XRD of CA (a), CA7dSrP (b), and CA14dSrP (c).

\subsubsection{FTIR}

Figure 3 depicts the vibrational spectra of CA, CA7dSrP, and CA14dSrP, indicating the interaction of SrP with CA upon its incorporation by a modified biomimetic methodology. The vibration band between 3050 and $3700 \mathrm{~cm}^{-1}$ was present in all the samples referring to $\mathrm{O}-\mathrm{H}$ stretching from unacetylated groups of cellulose, however, there was a small band for CA membranes [13]. This is possibly because water molecules tend to have weaker interactions with the solvent than with the water itself [59]. Additionally, two bands at 2975 and $2850 \mathrm{~cm}^{-1}$ related to symmetrical $\mathrm{CH}$ and asymmetrical $\mathrm{CH}_{2}$, a band at $750 \mathrm{~cm}^{-1}$ for $\mathrm{C}=\mathrm{O}$ stretching, and two bands at 1239 and $1050 \mathrm{~cm}^{-1}$ due to $\mathrm{C}-\mathrm{O}$ are depicted in Figure $3 a[55,59]$. In Figure 3b,c, the CA7dSrP and CA14dSrP samples, besides the characteristic spectrum of CA, showed the $863 \mathrm{~cm}^{-1}$ band referring to $\mathrm{P}-\mathrm{O}(\mathrm{H})$ stretching $[36,60]$. $\mathrm{CO}_{3}{ }^{2-}$ gives rise to weaker peaks around $600 \mathrm{~cm}^{-1}$ and more intense ones at 1568 and $1434 \mathrm{~cm}^{-1}[60,61]$. The previous $2850 \mathrm{~cm}^{-1}$ band corresponding to the $\mathrm{C}-\mathrm{H}$ stretch, $1374 \mathrm{~cm}^{-1}$ to the $\mathrm{C}-\mathrm{H}$ methyl rock. The increase near to $3600 \mathrm{~cm}^{-1}$ means an augmentation of the strength of hydrogen bonding (adsorbed water) compared to CA only, being related to the HA spectrum [59]. FTIR measurements affirmed the band assignments and additional functional group bands observed. The results indicate the presence of carbonated HA and SrHA. Despite a long period of contact between the CA interface and solution of $\mathrm{m}-\mathrm{SBF}$ in CA14dSrP, its spectrum coincided mostly with that of CA7dSrP. 


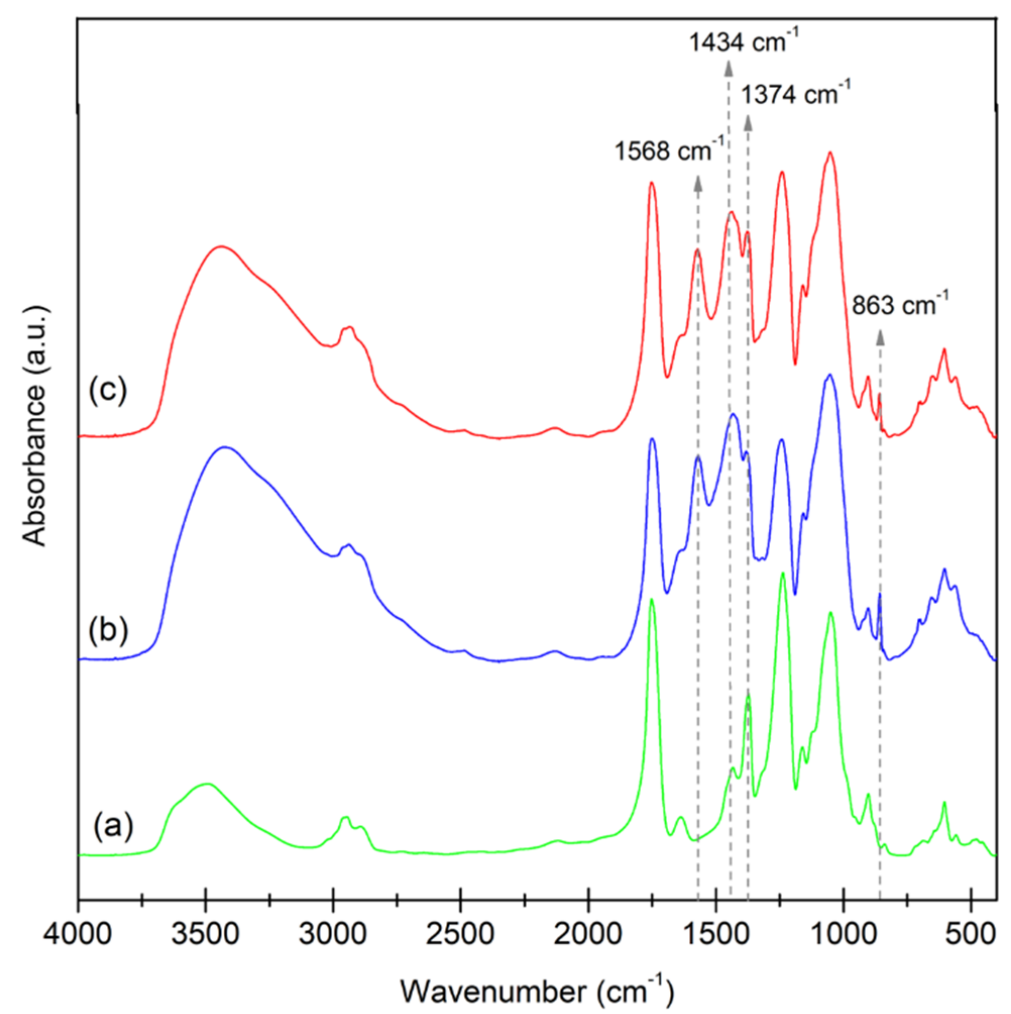

Figure 3. Vibrational spectra in the infrared region of the CA (a), CA7dSrP (b), and CA14dSrP (c).

\subsection{Bioactivity}

The liquid-absorbing ability (in \%) for the CA was studied using SBF and m-SBF as solvents to investigate the interaction of the media with the membrane before and after submitting the membrane to a solution with a higher ion concentration. Since in this work, SBF modified with $\mathrm{SrCl}_{2}$ instead of $\mathrm{CaCl}_{2}$ was used for synthesizing $\mathrm{SrP}, \mathrm{SBF}$ and $\mathrm{m}-\mathrm{SBF}$ were utilized for understanding the absorbing behavior. The systems reached equilibrium after about 2 min in SBF and $\mathrm{m}$-SBF since it no significant difference overtime for each system was observed according to the Kruskal-Wallis test. The CA in m-SBF showed the highest absorption capacity with an average ratio of around 3.33, in contrast to SBF, 1.83 , which is considered statistically significant. The evaluation of liquid uptake gave information on the effect of ionic strength.

The membrane in SBF containing $\mathrm{Sr}^{2+}$ showed a dramatic improvement of liquidabsorbing ability if this ability is compared when using SBF, as shown in Figure 4. The absorption was enhanced due to the greater concentration of polar constituents such as metal ions, which led to an increase in osmotic pressure between the membrane and the swelling solution [62]. Their presence and the existence of hydrophilic groups $(-\mathrm{OH})$ in CA enable that, in addition to hydrogen bonds, electrostatic and van der Waals interactions are also created in the liquid-solid interface. As a result, regarding the electronic properties of the cations in $\mathrm{m}-\mathrm{SBF}$, the interplay between these forces can be favored [14]. $\mathrm{Ca}^{2+}$, for example, is usually present in SBF composition, which is used for producing SrP in the biomimetic method; however, in $\mathrm{m}-\mathrm{SBF}$, it was replaced by $\mathrm{Sr}^{2+}$. In our study, instead of $\mathrm{Ca}^{2+}, \mathrm{Sr}^{2+}$ was used because of its interesting properties for bone repair and their similarity in ionic radii and valence $(2+)$, and common biochemical route that would contribute to keeping the adsorbent capability and biological function. The m-SBF solution was used to induce SrP nucleation and growth into the CA membrane after contact for seven days and 14 days. Pan et al. showed that as the $\mathrm{Sr}^{2+}$ content was augmented in HA, so did the solubility of the hybrid [58]. Conversely, later, Luz et al.'s study suggested that $\mathrm{Sr}^{2+}$ presence contributed to increasing the solubility of the scaffold, and thus, its swelling degree [36]. 


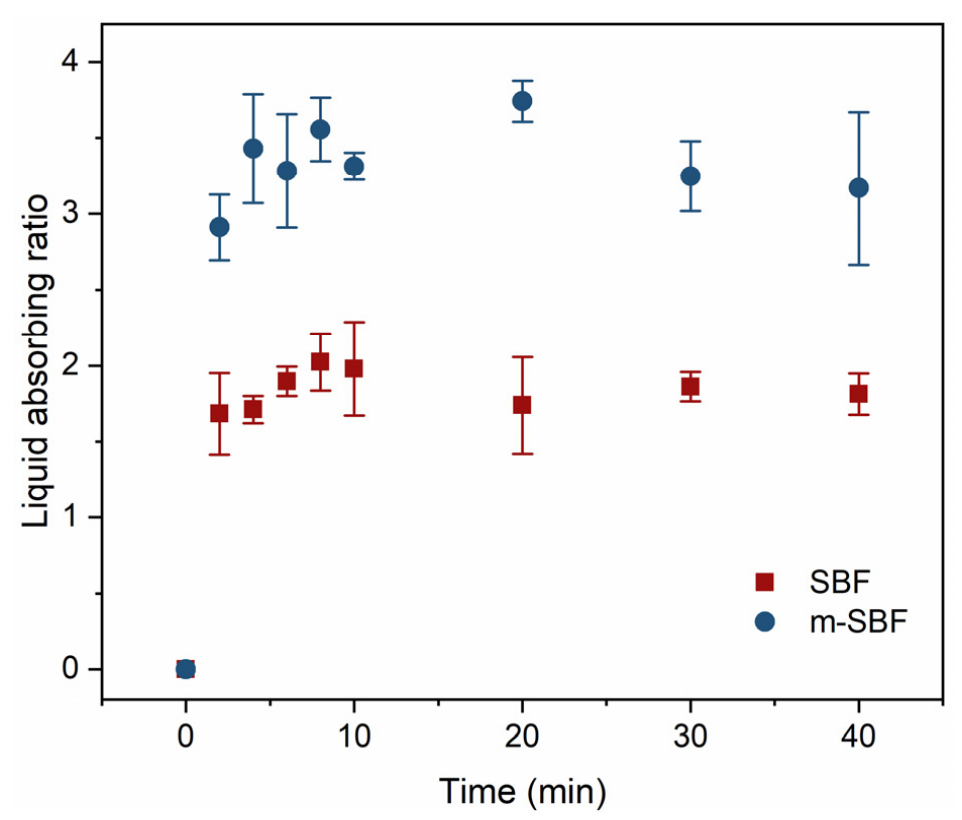

Figure 4. Liquid absorbing ratio of CA in SBF and m-SBF. The Kruskal-Wallis test was performed with a $p$-value of $<0.05$ being considered significant.

EDX chemically verified the ability of the material to induce apatite formation on its surface when immersed in $\mathrm{m}-\mathrm{SBF}$ after seven and 14 days [54]. Figure 5a shows the chemical element mapping of CA, where, as expected, no percentage of the Sr element was found, and pores were evident. After the treatment with m-SBF for seven days, in CA7dSrP, $1.7 \%$ of $\mathrm{Sr}$ and $0.7 \%$ of P elements were identified in EDX (see Figure $5 \mathrm{~b}$ ). In CA14dSrP, a percentage of about $1.5 \%$ of $\mathrm{Sr}$ and $0.5 \%$ of $\mathrm{P}$ was observed (see Figure $5 \mathrm{c}$ ).

Unlike CA and CA7dSrP (Figure 5a,b), clusters of SrP were evident in CA14dSrP. A high internalization by the CA membrane and the coating with other salts of $\mathrm{m}-\mathrm{SBF}$ and the characterized layer level and the low penetration of the EDX technique may have represented an obstacle in detecting the Sr element in the CA7dSrP and CA14dSrP samples.

A lower percentage of Sr was observed in CA7dSrP and CA14dSrP (Figure 5b,c), but still, the element was identifiable. To confirm its presence through other techniques, aliquots of the reaction solution were analyzed by atomic absorption spectroscopy (AAS) during the synthesis of the hybrids after seven and 14 days corresponding to CA7dSrP and CA14dSrP, respectively.

Figure 6 displays the amount of $\mathrm{Sr}^{2+}$ adsorbed on the CA membrane in both methods at the original concentration of $\mathrm{Sr}^{2+}$ in the m-SBF solution. The hybrid membranes presented an average percentage adsorption of about $92.3 \%$ and $96.1 \%$, showing a statistically significant difference between them, considering a $p$-value of less than 0.05 . Therefore, we suppose that the EDX technique in this work was not sensitive enough to discriminate or reach layers covered by a greater quantity of $\mathrm{Sr}^{2+}$ metal ions and AAS successfully proved its adsorption to the CA matrix. 

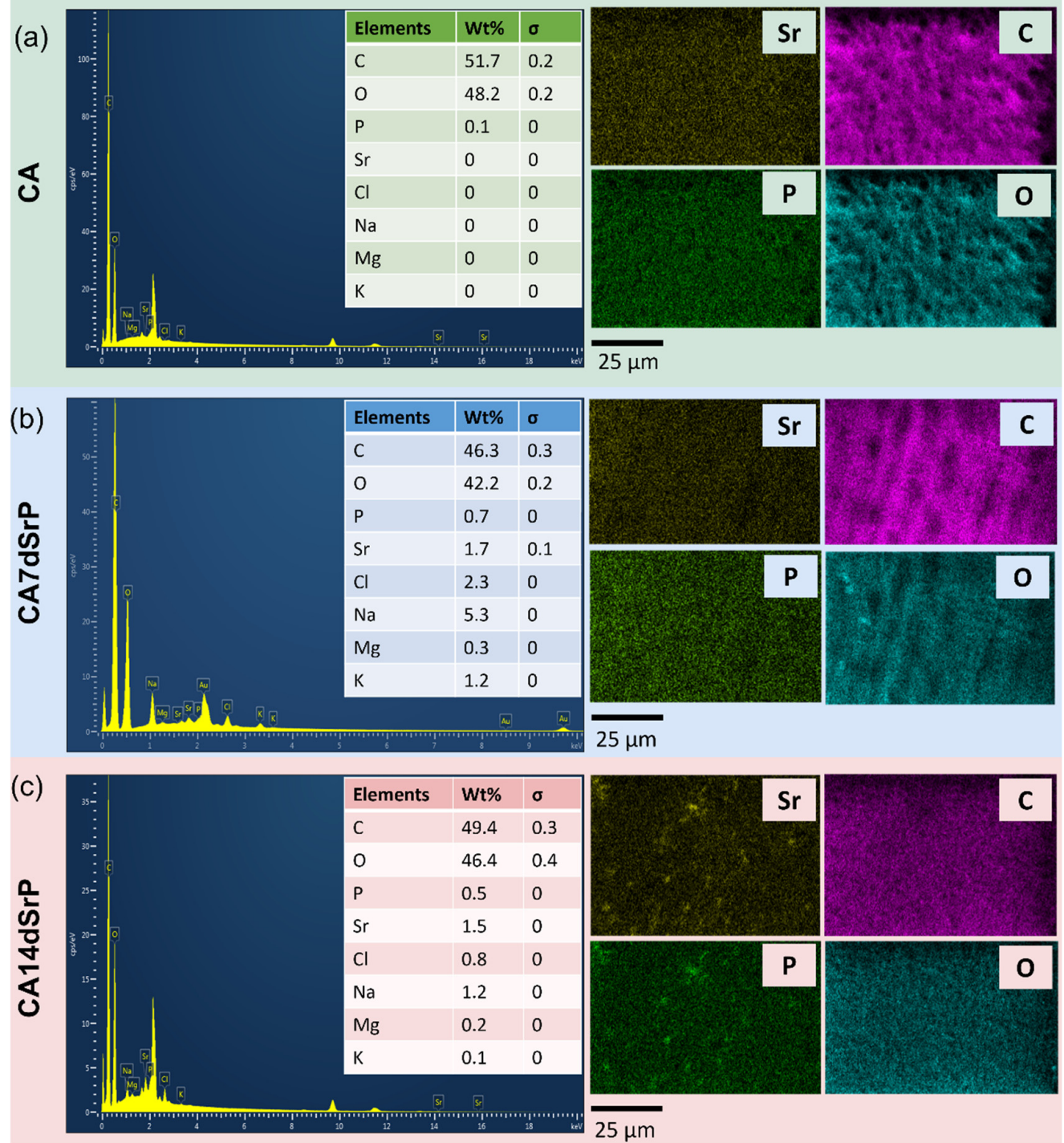

Figure 5. Scanning electron microscopy images of the surfaces and EDX maps ( $\mathrm{Sr}, \mathrm{C}, \mathrm{P}$, and O) of CA (a), CA7dSrP (b)), and CA14dSrP (c).

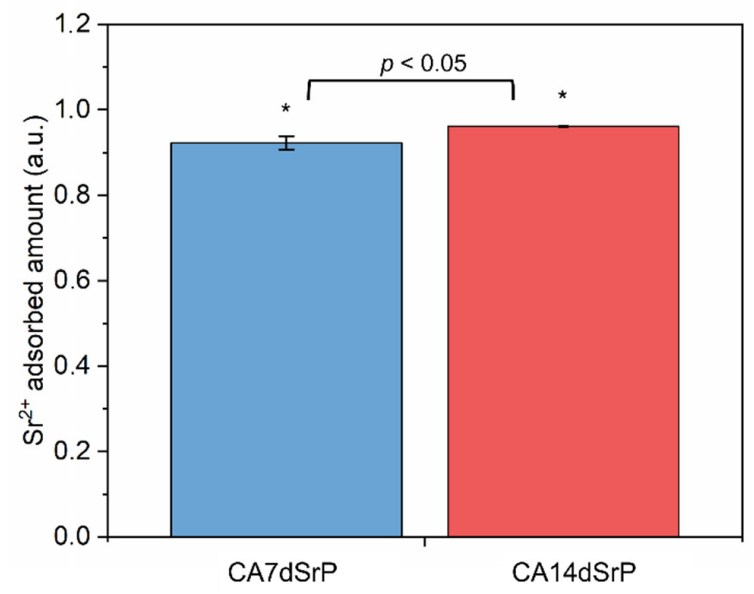

Figure 6. Relative $\mathrm{Sr}^{2+}$ adsorption of $\mathrm{CA}$ in $\mathrm{m}-\mathrm{SBF}$ solution after 7 and 14 days for production of CA7dSrP and CA14dSrP, respectively. One-way ANOVA followed by Tukey's post-hoc multiple comparison tests were performed for statistical analysis. A $p$-value of $<0.05$ was considered significant $\left(^{*}\right)$. 


\subsection{In Vitro Degradability}

A long-term physical degradation study was performed to evaluate the stability of the coating in stressing conditions. This parameter was estimated by measuring the weight loss (in \%) and indicates possible changes in the structure after SrP incorporation compared to CA. CA has a partial hydrophobic nature that confers specific stability for its structure. The molecular weight of CA is related to the number of ester bonds in the acetyl group and, as it increases, it becomes more difficult to degrade because more groups need to be cleaved. As a result, cellulose monoacetate with the lowest acetyl content (about $29 \%$ ) was used in this work [11]. The insertion of metal ions into the structure, like $\mathrm{Sr}^{2+}$ and other constituents of $\mathrm{m}$-SBF, through adsorption, can lead to water molecules surrounding the solid-liquid interface interacting and hydrating these metals forming complexes. This hydration can increase strength loss, loss of mass integrity, solubilization of the polymeric matrix, and degradability $[63,64]$. The degradation process can occur by several mechanisms, besides the physical already described, hydrolysis, oxidation, and enzymatic reactions can also occur, releasing wear particles in the biological media [20]. Therefore, a first biocompatible material can become toxic as fragmented particles can elicit an unwanted immunological process in the body. The materials produced in this work showed a similar degradation behavior for all the samples according to the first derivative calculated through the average value of degradability (Figure 7).

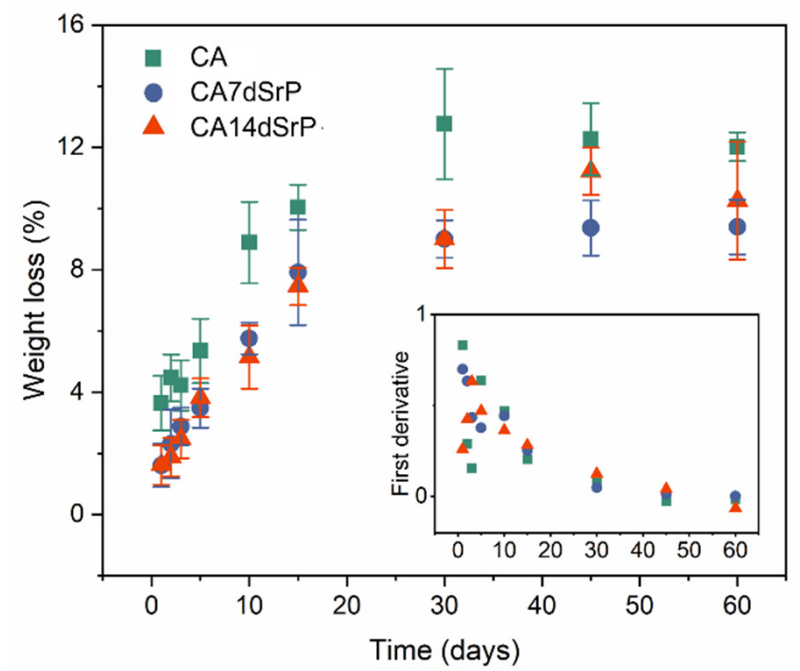

Figure 7. Degradation behavior during 60 days in PBS solution of the CA, CA7dSrP, and CA14dSrP.

Nevertheless, after one, 10, and 30 days of exposure to the stressful environment, it was shown that the CA was significantly different from the CASrP samples, showing raised values of material loss. Additionally, at two, three, and 45 days, CA14dSrP was considered different statistically from CA, but close to CA7dSrP. In general, the percentage of mass loss was higher for CA concerning the CASrP samples and a higher degradation rate was observed mainly in the initial period, reaching a certain stability up to 30 days. $\mathrm{Ge}$ et al. reported a material close to ours, prepared by the biomimetic method and $\mathrm{Sr}^{2+}$-doped, but different because it used poly (L-lactic acid) as the polymer component. The authors obtained a higher hydrophilicity after nucleation of $\mathrm{SrP}$ in the structure and diminished the degradability percentage [32]. The CA7dSrP and CA14dSrP presented a similar degradation profile. Non-significant differences between the bulk values were observed at all times. Although a modification of crystallinity was verified because of the higher quantity of $\mathrm{Sr}^{2+}$ in CA14dSrP (Figure 2a,b), this change had no significant effect on the degradation behavior of CA7dSrP and CA14dSrP. 


\section{4. $\mathrm{Sr}^{2+}$ Release}

Figure 8 displays a graph of the amount of $\mathrm{Sr}$ dissolved into the cell culture medium over a $24 \mathrm{~h}$ period in the absence (indirect method) of cells. Although in vivo conditions are more complex than in vitro, the study of degradation behavior in culture media conditions containing fetal bovine serum (FBS) gives insights into the degradability in real conditions, and thus the $\mathrm{Sr}^{2+}$ release resulting from this process [65]. Furthermore, the presence of FBS is considered to slow this process since it simulates the scenario in the biological fluid with proteins that can adsorb into the surface of the material [66,67].

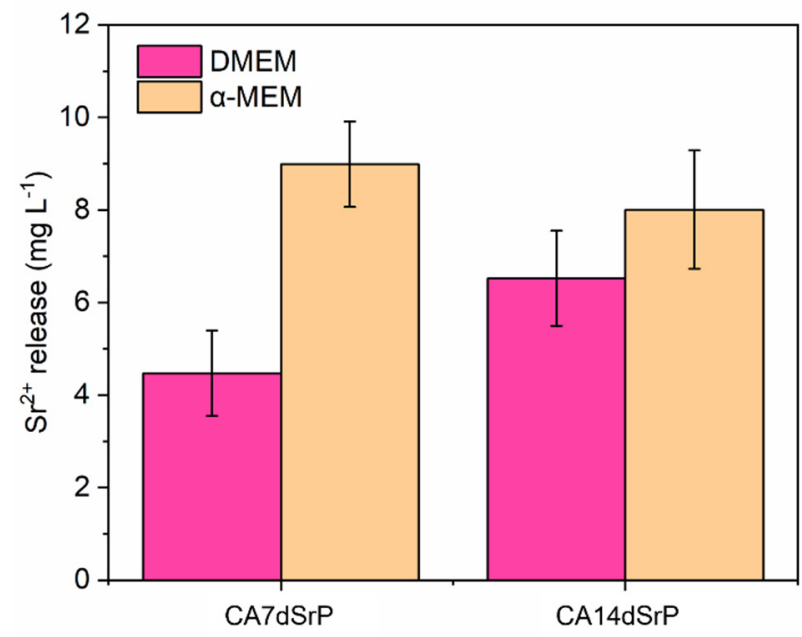

Figure 8. The total amount of $\mathrm{Sr}^{2+}$ dissolved in the culture media in the absence of cells after $24 \mathrm{~h}$ of exposure to CA7dSrP and CA14dSrP.

The quantity of metal ions released into the cell culture medium was 4.63 and $6.52 \mathrm{mg} \cdot \mathrm{L}^{-1}$ for CA7dSrP and CA14dSrP exposed to the DMEM corresponding to L929 cells, while it was 9 and $8 \mathrm{mg} \cdot \mathrm{L}^{-1}$ for CA7dSrP and CA14dSrP in the $\alpha$-MEM media referred to MC3T3-E1 cells, respectively. Thus, a slightly increased release was observed in the culture medium of osteoblasts. The presence of a superior quantity of amino acids [68] and glucose [69] in the composition of DMEM in comparison to $\alpha$-MEM media may have driven the interaction between these components with the material and reduced the degradation in DMEM, as mentioned previously in the case of FBS addition in the test media. This is possibly because proteins from serum media may physically adsorb through electrostatic interaction between their amino groups with groups in the CA coating and hydrophobic interactions, helping to retain the membrane structure [66,70]. Additionally, the high glucose concentration in DMEM may influence $\mathrm{Sr}^{2+}$ availability through interaction between the glucose and $\mathrm{Sr}^{2+}$ metal ions. Zuberek et al. showed that the difference in glucose concentration in the culture medium for cell maintenance negatively affected silver nanoparticle toxicity and oxidative stress [69].

\subsection{Cell Cytotoxicity}

GBR therapy involves stimulating the reconstitution of bone and occurs mainly using membranes to isolate the damaged area from other tissues that can invade and interfere with the repair process. The membrane serves as a support, simulating the extracellular matrix found in bone composition and interaction between biomolecules and the scaffold [71]. Fibroblasts and osteoblasts found in the body play a crucial role in the homeostasis of this structure, synthesizing components of the innate immune system and inducing bone healing, respectively. To favor this process, a coating for bone implants must trigger an appropriate acute inflammatory response and, ideally, ensure bone formation while attending to the exclusion principle during the bone healing process. In addition to biocompatibility, implant degradability is an imperative factor that must be considered when designing a scaffold for bone repair, as it would avoid the need for a second surgery to remove 
this implant after tissue repair. In addition, however, it is necessary to ensure that particles from implant degradation are neither toxic nor inappropriately activating the innate immune system.

In our work, we evaluated the cytotoxicity of the materials by the indirect assay in which fibroblasts and osteoblasts cells were exposed to the sample extracts containing some particles and $\mathrm{Sr}^{2+}$ released from the materials during the extraction time. As a result, the cellular response was elicited not by the produced composites themselves, but as a consequence of their soluble degradation products after incubation at $37^{\circ} \mathrm{C}$ for $24 \mathrm{~h}$ [65]. Figure 9 shows the cellular viability (in \%) results from L-929 mouse fibroblasts and mouse osteoblasts after their exposure to CA and CASrP composites to the control (cells exposed only to the supplemented medium). The L-929 viability was higher for CASrP materials than CA, obtaining an average percentage of $75 \%, 86 \%$, and $83 \%$ for $24 \mathrm{~h}$ and $70 \%, 92 \%$, and $88 \%$ for $48 \mathrm{~h}$ after exposure to the media containing extracts of $\mathrm{CA}, \mathrm{CA} 7 \mathrm{dSrP}$, and CA14dSrP, respectively (Figure 9a). Although cell viability increased after $48 \mathrm{~h}$ for CASrP composites, this difference was not considered statistically significant. In addition to L-929 cells, the MC3T3-E1 cells enabled us to analyze the cell viability of a bone cell line related to the formation of bone tissue. After incubation with the extracts of the CA, CA7dSrP, and CA14dSrP for $24 \mathrm{~h}$, the average percentage of MC3T3-E1 cells obtained was $89 \%, 105 \%$, and $106 \%$, respectively, while for $48 \mathrm{~h}$, it was $51 \%, 115 \%$, and $107 \%$, respectively (Figure $9 \mathrm{~b}$ ). The cell viability of CA decreased significantly after $48 \mathrm{~h}$ of exposure, while the incorporation of SrP on CA improved the biocompatibility of the polymeric matrix for both fibroblasts and osteoblasts. Since the HA produced was similar to the biological apatite, the inorganic component may have contributed to improved compatibility, while $\mathrm{Sr}^{2+}$ presence in the structure increased its solubility and the release of $\mathrm{Sr}^{2+}$, which may lead to the proliferation of osteoblasts [72]. Several studies have demonstrated the osteogenic potential of SrHA doped composites [32,51,52,72]. Ge et al. reported increased bone volume and ALP activity, which is an important biomarker referred to in osteoblast differentiation, after the addition of HA into poly(L-lactic acid), and higher protein adsorption, bone volume, and ALP activity with the addition of $\mathrm{Sr}^{2+}$ into HA/poly(L-lactic acid) [32]. Likewise, Zhang et al. evidenced a higher ALP activity after incorporating SrHA into a polymeric structure [52]. In another work, it was shown that depending on the concentration of $\mathrm{Sr}^{2+}$ in the composite, a similar response with the HA of concern can be obtained. Increasing the $\mathrm{Sr}^{2+}$ concentration proportion in the composite highly improved ALP activity [72]. Nevertheless, the quantity of $\mathrm{Sr}^{2+}$ obtained for both samples after seven and 14 days of treatment in m-SBF for synthesizing CA7dSrP and CA14dSrP was not significantly different concerning chemical composition and degradability behavior. On the other hand, $\mathrm{Sr}^{2+}$ absorption in CASrP production and $\mathrm{Sr}^{2+}$ release in the culture media pointed out increased adsorption in $\mathrm{m}-\mathrm{SBF}$ and metal ion release in DMEM for CA14dSrP.

Overall, CA is considered as a biocompatible polymer [19,73], presenting cell viability above $70 \%$, referring to the required minimum value according to the international standard ISO 10993-5:2009. ISO 10993-5:2009 comprises the evaluation of the cytocompatibility of medical devices. However, the CA produced in our work resulted in $51 \%$ and $70 \%$ of living osteoblasts and fibroblasts after $48 \mathrm{~h}$ of exposure to the extracts, respectively. The greater and variation of the cytotoxicity of $\mathrm{CA}$, despite this, were not considered statistically different at $24 \mathrm{~h}$ and $48 \mathrm{~h}[19,73]$, may have resulted from its degradation in the initial time $(24 \mathrm{~h}$ ), producing fragments of CA, acetic acid, and cellulose [74,75]; the composition media $[68,69]$ as well as resulting from the lack of osteogenic activity associated with this material, while the presence of SrP may have favored increased compatibility because of its similarity to $\mathrm{HA}$ and $\mathrm{Sr}^{2+}$ release $[32,35,42,43]$. It is known that $\mathrm{Sr}^{2+}$ toxicity is dosedependent [42,72], on the other hand, HA is a known biocompatible constituent that also improves the physical properties of composites.

In contrast to organisms, cell cultures are a more sensitive model, and, naturally, as the material and the culture media are maintained in contact for a specific time, products of membrane degradation are released in the culture medium and the extract containing 
these degraded materials may intensify the toxicity, as shown by Figure 9 [76]. However, the release of $\mathrm{Sr}^{2+}$ in the culture media improved the biocompatibility of CA itself $[43,72]$. Additionally, the superior concentration of $\mathrm{Sr}^{2+}$ obtained in the extract after $24 \mathrm{~h}$ in $\alpha$-MEM followed the high cell viability observed for CA7dSrP and CA14dSrP in osteoblasts to fibroblasts (see Figure 8). The enhanced cell viability, even superior to the control, may indicate cell proliferation or increase in metabolic activity of the osteoblasts [43,72].

(a)

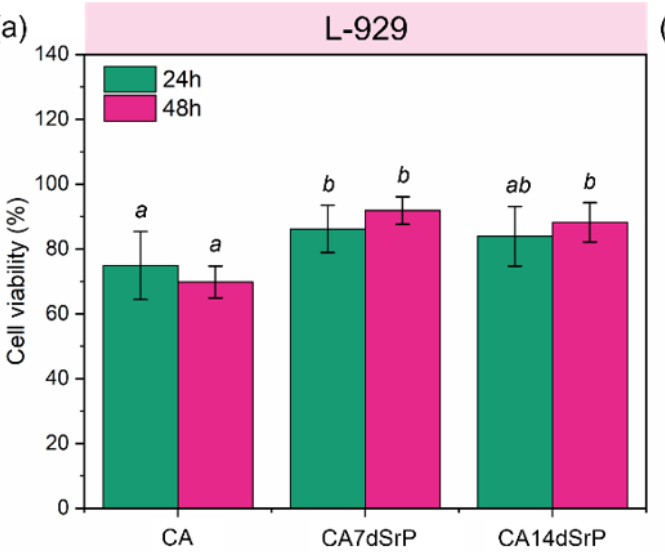

(b)

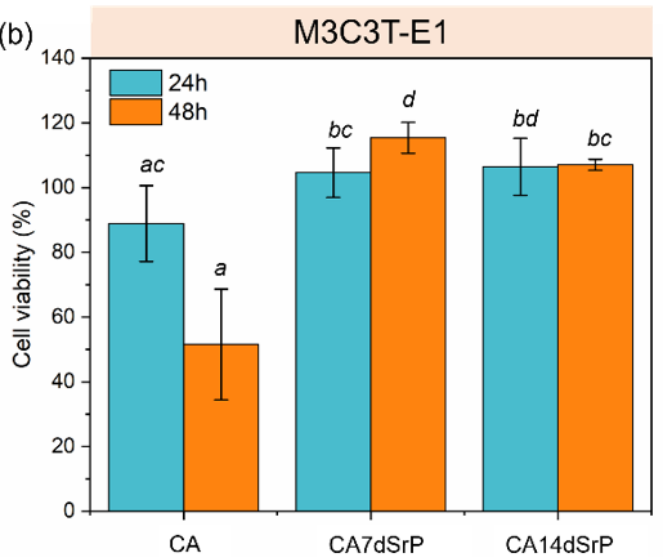

Figure 9. L-929 mouse fibroblast (a) and MC3T3-E1 osteoblast (b) viability of CA, CA7dSrP, and CA14dSrP after 24 and $48 \mathrm{~h}$. Letters inside the graphs indicate homogeneous groups (treatments with non-significant differences). Two-way ANOVA followed by Tukey's post-hoc multiple comparison tests were performed for statistical analysis of fibroblasts data, while the Kruskal-Wallis test was performed for the osteoblast data. A $p$-value of $<0.05$ was considered significant.

\section{Conclusions}

In this work, we report on the incorporation of SrP into CA membranes for the first time, effectively producing two promising composites for GBR (CA7dSrP and CA14dSrP). CA is highly relevant as a support to SrP crystal nucleation and scaffold design. In addition, the coating effectiveness was investigated by evaluating its bioactivity and biocompatibility for implant applications.

The SrP formation modified the morphology and physicochemical properties of the hybrid coating, leading to the formation of SrP sphere-like crystals, a slight decrease in the long-term degradation process, and an augmentation in crystallinity. Additionally, this inorganic component played a significant role in biocompatibility in comparison to CA alone.

Finally, even though no statistical difference was found in the properties of CA7dSrP and CA14dSrP and the studies were performed in vitro indirectly, the $\mathrm{Sr}^{2+}$ release study allowed us to quantify the concentration of $\mathrm{Sr}^{2+}$ in the exposure media, fairly well representing the body conditions, and showing that it was in an optimal dose for bone regeneration since the osteoblast viability $(>100 \%)$ was boosted, instigating future research.

Author Contributions: Conceptualization, R.S.V.; Methodology, A.L.d.B.S., M.A.C., and F.K.A.; Validation, M.T.M., A.L.d.B.S., and F.K.A.; Formal analysis, M.T.M.; Investigation, A.L.d.B.S. and M.A.C.; Resources, R.S.V. and E.R.-C.; Data curation, M.T.M.; Writing-original draft preparation, M.T.M.; Writing-review and editing, R.S.V. and E.R.-C.; Visualization, M.T.M. and A.L.d.B.S.; Supervision, R.S.V.; Project administration, R.S.V.; Funding acquisition, R.S.V. and E.R.-C. All authors have read and agreed to the published version of the manuscript.

Funding: This research was funded by FUNCAP/CNPq (PNE-0112-00049.01.00/16), CNPq (421039/ 2016-7) and PROCAD/CAPES (88881.068439/2014-01). E.R.-C. thanks project RTI2018-099668-BC22 of Ministerio de Ciencia, Innovación y Universidades, and project UMA18-FEDERJA-126 of Junta de Andalucía and FEDER Funds.

Institutional Review Board Statement: Not applicable. 
Informed Consent Statement: Not applicable.

Data Availability Statement: Not applicable.

Acknowledgments: The authors acknowledge the Brazilian funding agencies CAPES (Coordenação de Aperfeiçoamento de Pessoal de Nível Superior), CNPq (Conselho Nacional de Desenvolvimento Científico e Tecnológico), FUNCAP (Fundação Cearense de Apoio ao Desenvolvimento Científico e Tecnológico), Universidade Federal do Ceará (UFC), and Embrapa Agroindústria Tropical for their technical and financial support.

Conflicts of Interest: The authors declare no conflict of interest.

\section{References}

1. Hu, C.; Ashok, D.; Nisbet, D.R.; Gautam, V. Bioinspired surface modification of orthopedic implants for bone tissue engineering. Biomaterials 2019, 219, 119366. [CrossRef]

2. Chocholata, P.; Kulda, V.; Babuska, V. Fabrication of scaffolds for bone-tissue regeneration. Materials 2019, 12, 568. [CrossRef]

3. Qiu, Z.Y.; Cui, Y.; Wang, X.M. Natural Bone Tissue and Its Biomimetic; Elsevier: Amsterdam, The Netherlands, 2019; Volume 10, ISBN 9780081027172.

4. An, J.; Leeuwenburgh, S.; Wolke, J.; Jansen, J. Mineralization processes in hard tissue: Bone. In Biomineralization and Biomaterials; Woodhead Publishing: Cambridge, UK, 2016; Volume 4, pp. 129-146. [CrossRef]

5. Fragal, E.H.; Cellet, T.S.P.; Fragal, V.H.; Witt, M.A.; Companhoni, M.V.P.; Ueda-Nakamura, T.; Silva, R.; Rubira, A.F. Biomimetic nanocomposite based on hydroxyapatite mineralization over chemically modified cellulose nanowhiskers: An active platform for osteoblast proliferation. Int. J. Biol. Macromol. 2019, 125, 133-142. [CrossRef] [PubMed]

6. Gao, C.; Zhao, K.; Wu, Y.; Gao, Q.; Zhu, P. Fabrication of strontium/calcium containing poly( $\gamma$-glutamic acid)-organosiloxane fibrous hybrid materials for osteoporotic bone regeneration. RSC Adv. 2018, 8, 25745-25753. [CrossRef]

7. Gouma, P.; Xue, R.; Goldbeck, C.P.; Perrotta, P.; Balázsi, C. Nano-hydroxyapatite-Cellulose acetate composites for growing of bone cells. Mater. Sci. Eng. C 2012, 32, 607-612. [CrossRef]

8. Xu, Z.L.; Lei, Y.; Yin, W.J.; Chen, Y.X.; Ke, Q.F.; Guo, Y.P.; Zhang, C.Q. Enhanced antibacterial activity and osteoinductivity of Ag-loaded strontium hydroxyapatite/chitosan porous scaffolds for bone tissue engineering. J. Mater. Chem. B 2016, 4, 7919-7928. [CrossRef] [PubMed]

9. Furko, M.; Balázsi, C. Calcium phosphate based bioactive ceramic layers on implant materials preparation, properties, and biological performance. Coatings 2020, 10, 823. [CrossRef]

10. Ganster, J.; Fink, H.P. Cellulose and cellulose acetate. In Bio-Based Plastics: Materials and Applications; Kabasci, S., Ed.; Wiley Online Library: Hoboken, NJ, USA, 2014; pp. 35-62. [CrossRef]

11. Tsiapla, A.R.; Karagkiozaki, V.; Bakola, V.; Pappa, F.; Gkertsiou, P.; Pavlidou, E.; Logothetidis, S. Biomimetic and biodegradable cellulose acetate scaffolds loaded with dexamethasone for bone implants. Beilstein J. Nanotechnol. 2018, 9, 1986-1994. [CrossRef] [PubMed]

12. Wsoo, M.A.; Shahir, S.; Mohd Bohari, S.P.; Nayan, N.H.M.; Razak, S.I.A. A review on the properties of electrospun cellulose acetate and its application in drug delivery systems: A new perspective. Carbohydr. Res. 2020, 491, 107978. [CrossRef] [PubMed]

13. Ramanathan, G.; Seleenmary Sobhanadhas, L.S.; Sekar Jeyakumar, G.F.; Devi, V.; Sivagnanam, U.T.; Fardim, P. Fabrication of biohybrid cellulose acetate-collagen bilayer matrices as nanofibrous spongy dressing material for wound-healing application. Biomacromolecules 2020, 21, 2512-2524. [CrossRef]

14. Azzaoui, K.; Lamhamdi, A.; Mejdoubi, E.M.; Berrabah, M.; Hammouti, B.; Elidrissi, A.; Fouda, M.M.G.; Al-Deyab, S.S. Synthesis and characterization of composite based on cellulose acetate and hydroxyapatite application to the absorption of harmful substances. Carbohydr. Polym. 2014, 111, 41-46. [CrossRef]

15. Pandele, A.M.; Comanici, F.E.; Carp, C.A.; Miculescu, F.; Voicu, S.I.; Thakur, V.K.; Serban, B.C. Synthesis and characterization of cellulose acetate-hydroxyapatite micro and nano composites membranes for water purification and biomedical applications. Vacuum 2017, 146, 599-605. [CrossRef]

16. Baharifar, H.; Honarvarfard, E.; Maleki, H. The potentials and applicatons of cellulose acetate in biosensor technology. Nanomed. Res. J. 2017, 2, 216-223. [CrossRef]

17. Rodríguez, K.; Gatenholm, P.; Renneckar, S. Electrospinning cellulosic nanofibers for biomedical applications: Structure and in vitro biocompatibility. Cellulose 2012, 19, 1583-1598. [CrossRef]

18. Hickey, R.J.; Pelling, A.E. Cellulose biomaterials for tissue engineering. Front. Bioeng. Biotechnol. 2019, 7, 1-15. [CrossRef] [PubMed]

19. Mousa, H.M.; Hussein, K.H.; Sayed, M.M.; Abd El-Rahman, M.K.; Woo, H.M. Development and characterization of cellulose/iron acetate nanofibers for bone tissue engineering applications. Polymer 2021, 13, 1339. [CrossRef]

20. Puls, J.; Wilson, S.A.; Hölter, D. Degradation of cellulose acetate-based materials: A review. J. Polym. Environ. 2011, 19, 152-165. [CrossRef]

21. Fischer, S.; Thümmler, K.; Volkert, B.; Hettrich, K.; Schmidt, I.; Fischer, K. Properties and applications of cellulose acetate. Macromol. Symp. 2008, 262, 89-96. [CrossRef] 
22. Candido, R.G.; Godoy, G.G.; Gonçalves, A. Characterization and application of cellulose acetate synthesized from sugarcane bagasse. Carbohydr. Polym. 2017, 167, 280-289. [CrossRef]

23. Zhong, Z.; Qin, J.; Ma, J. Cellulose acetate/hydroxyapatite/chitosan coatings for improved corrosion resistance and bioactivity. Mater. Sci. Eng. C 2015, 49, 251-255. [CrossRef] [PubMed]

24. Märtson, M.; Viljanto, J.; Laippala, P.; Saukko, P. Connective tissue formation in subcutaneous cellulose sponge implants in the rat. Eur. Surg. Res. 1998, 30, 419-425. [CrossRef] [PubMed]

25. Pandele, A.M.; Neacsu, P.; Cimpean, A.; Staras, A.I.; Miculescu, F.; Iordache, A.; Voicu, S.I.; Thakur, V.K.; Toader, O.D. Cellulose acetate membranes functionalized with resveratrol by covalent immobilization for improved osseointegration. Appl. Surf. Sci. 2018, 438, 2-13. [CrossRef]

26. Kim, M.; Yeo, M.; Kim, M.; Kim, G. Biomimetic cellulose/calcium-deficient-hydroxyapatite composite scaffolds fabricated using an electric field for bone tissue engineering. RSC Adv. 2018, 8, 20637-20647. [CrossRef]

27. Atila, D.; Keskin, D.; Tezcaner, A. Crosslinked pullulan/cellulose acetate fibrous scaffolds for bone tissue engineering. Mater. Sci. Eng. C 2016, 69, 1103-1115. [CrossRef]

28. Abdelaziz, D.; Hefnawy, A.; Al-Wakeel, E.; El-Fallal, A.; El-Sherbiny, I.M. New biodegradable nanoparticles-in-nanofibers based membranes for guided periodontal tissue and bone regeneration with enhanced antibacterial activity. J. Adv. Res. 2021, 27, 21-62. [CrossRef]

29. Rad, R.M.; Alshemary, A.Z.; Evis, Z.; Keskin, D.; Tezcaner, A. Cellulose acetate-gelatin-coated boron-bioactive glass biocomposite scaffolds for bone tissue engineering. Biomed. Mater. 2020, 15, 065009. [CrossRef]

30. Hatamie, S.; Mohamadyar-Toupkanlou, F.; Mirzaei, S.; Ahadian, M.M.; Hosseinzadeh, S.; Soleimani, M.; Sheu, W.J.; Wei, Z.H.; Hsieh, T.F.; Chang, W.C.; et al. Cellulose acetate/magnetic graphene nanofiber in enhanced human mesenchymal stem cells osteogenic differentiation under alternative current magnetic field. Spin 2019, 9, 1-10. [CrossRef]

31. Zhao, Y.; Chen, J.; Chou, A.H.K.; Li, G.; LeGeros, R.Z. Nonwoven silk fibroin net/nano-hydroxyapatite scaffold: Preparation and characterization. J. Biomed. Mater. Res. Part A 2009, 91, 1140-1149. [CrossRef]

32. Ge, M.; Ge, K.; Gao, F.; Yan, W.; Liu, H.; Xue, L.; Jin, Y.; Ma, H.; Zhang, J. Biomimetic mineralized strontium-doped hydroxyapatite on porous poly (L-lactic acid) scaffolds for bone defect repair. Int. J. Nanomed. 2018, 13, 1707-1721. [CrossRef]

33. Rodríguez, K.; Renneckar, S.; Gatenholm, P. Biomimetic calcium phosphate crystal mineralization on electrospun cellulose-based scaffolds. ACS Appl. Mater. Interfaces 2011, 3, 681-689. [CrossRef]

34. Torgbo, S.; Sukyai, P. Fabrication of microporous bacterial cellulose embedded with magnetite and hydroxyapatite nanocomposite scaffold for bone tissue engineering. Mater. Chem. Phys. 2019, 237, 121868. [CrossRef]

35. Luz, E.P.C.G.; das Chagas, B.S.; de Almeida, N.T.; de Fátima Borges, M.; Andrade, F.K.; Muniz, C.R.; Castro-Silva, I.I.; Teixeira, E.H.; Popat, K.; de Freitas Rosa, M.; et al. Resorbable bacterial cellulose membranes with strontium release for guided bone regeneration. Mater. Sci. Eng. C 2020, 116, 111175. [CrossRef] [PubMed]

36. Luz, E.P.C.G.; Borges, M.d.F.; Andrade, F.K.; Rosa, M.d.F.; Infantes-Molina, A.; Rodríguez-Castellón, E.; Vieira, R.S. Strontium delivery systems based on bacterial cellulose and hydroxyapatite for guided bone regeneration. Cellulose 2018, 25, 6661-6679. [CrossRef]

37. Kargozar, S.; Montazerian, M.; Fiume, E.; Baino, F. Multiple and promising applications of strontium (Sr)-containing bioactive glasses in bone tissue engineering. Front. Bioeng. Biotechnol. 2019, 7, 161. [CrossRef] [PubMed]

38. Baheiraei, N.; Eyni, H.; Bakhshi, B.; Najafloo, R.; Rabiee, N. Effects of strontium ions with potential antibacterial activity on in vivo bone regeneration. Sci. Rep. 2021, 11, 1-9. [CrossRef] [PubMed]

39. Anastasiou, A.D.; Nerantzaki, M.; Gounari, E.; Duggal, M.S.; Giannoudis, P.V.; Jha, A.; Bikiaris, D. Antibacterial properties and regenerative potential of $\mathrm{Sr}^{2+}$ and $\mathrm{Ce}^{3+}$ doped fluorapatites; a potential solution for peri-implantitis. Sci. Rep. 2019, 9, 1-11. [CrossRef] [PubMed]

40. Cochis, A.; Barberi, J.; Ferraris, S.; Miola, M.; Rimondini, L.; Vernè, E.; Yamaguchi, S.; Spriano, S. Competitive surface colonization of antibacterial and bioactive materials doped with strontium and/or silver ions. Nanomaterials 2020, 10, 120. [CrossRef]

41. Frasnelli, M.; Cristofaro, F.; Sglavo, V.M.; Dirè, S.; Callone, E.; Ceccato, R.; Bruni, G.; Cornaglia, A.I.; Visai, L. Synthesis and characterization of strontium-substituted hydroxyapatite nanoparticles for bone regeneration. Mater. Sci. Eng. C 2017, 71, 653-662. [CrossRef] [PubMed]

42. Zhang, W.; Shen, Y.; Pan, H.; Lin, K.; Liu, X.; Darvell, B.W.; Lu, W.W.; Chang, J.; Deng, L.; Wang, D.; et al. Effects of strontium in modified biomaterials. Acta Biomater. 2011, 7, 800-808. [CrossRef]

43. Lindahl, C.; Pujari-Palmer, S.; Hoess, A.; Ott, M.; Engqvist, H.; Xia, W. The influence of Sr content in calcium phosphate coatings. Mater. Sci. Eng. C 2015, 53, 322-330. [CrossRef]

44. Rajabnejadkeleshteri, A.; Kamyar, A.; Khakbiz, M.; Bakalani, Z.L.; Basiri, H. Synthesis and characterization of strontium fluor-hydroxyapatite nanoparticles for dental applications. Microchem. J. 2020, 153, 104485. [CrossRef]

45. Bigi, A.; Boanini, E.; Capuccini, C.; Gazzano, M. Strontium-substituted hydroxyapatite nanocrystals. Inorg. Chim. Acta 2007, 360, 1009-1016. [CrossRef]

46. Wei, Y.; Gao, H.; Hao, L.; Shi, X.; Wang, Y. Constructing a Sr ${ }^{2+}$-substituted surface hydroxyapatite hexagon-like microarray on 3D-plotted hydroxyapatite scaffold to regulate osteogenic differentiation. Nanomaterials 2020, 10, 1672. [CrossRef]

47. Ehret, C.; Sagardoy, T.; Siadous, R.; Bareille, R.; Rey, S.; Pechev, S. Strontium-doped hydroxyapatite polysaccharide materials effect on ectopic bone formation. PLoS ONE 2017, 12, 1-21. [CrossRef] [PubMed] 
48. Shi, J.; Li, Y.; Gu, Y.; Qiao, S.; Zhang, X.; Lai, H. Effect of titanium implants with strontium incorporation on bone apposition in animal models: A systematic review and meta-Analysis. Sci. Rep. 2017, 7, 1-10. [CrossRef] [PubMed]

49. Chen, X.B.; Chong, K.; Abbott, T.B.; Birbilis, N.; Easton, M.A. Biocompatible Strontium-Phosphate and Manganese-Phosphate Conversion Coatings for Magnesium and Its Alloys; Elsevier: Amsterdam, The Netherlands, 2015; Volume 2, ISBN 9781782420835.

50. Sergi, R.; Bellucci, D.; Cannillo, V. A comprehensive review of bioactive glass coatings: State of the art, challenges and future perspectives. Coatings 2020, 10, 757. [CrossRef]

51. Luo, X.; Barbieri, D.; Zhang, Y.; Yan, Y.; Bruijn, J.D.; Yuan, H. Strontium-containing apatite/poly lactide composites favoring osteogenic differentiation and in vivo bone formation. ACS Biomater. Sci. Eng. 2015, 1, 85-93. [CrossRef]

52. Zhang, X.Y.; Chen, Y.P.; Han, J.; Mo, J.; Dong, P.F.; Zhuo, Y.H.; Feng, Y. Biocompatiable silk fibroin/carboxymethyl chitosan/strontium substituted hydroxyapatite/cellulose nanocrystal composite scaffolds for bone tissue engineering. Int. J. Biol. Macromol. 2019, 136, 1247-1257. [CrossRef] [PubMed]

53. Maia, M.T.; Patrícia, É.; Gomes, C.; Karine, F.; Rosa, M.D.F.; Borges, M.D.F.; Arcanjo, R.A.; Vieira, R.S.; Torres, M.; Patrícia, É.; et al. Advances in bacterial cellulose/strontium apatite composites for bone applications. Polym. Rev. 2021, 1-29. [CrossRef]

54. Bohner, M.; Lemaitre, J. Can bioactivity be tested in vitro with SBF solution? Biomaterials 2009, 30, 2175-2179. [CrossRef] [PubMed]

55. Murphy, D.; de Pinho, M.N. An ATR-FTIR study of water in cellulose acetate membranes prepared by phase inversion. J. Memb. Sci. 1995, 106, 245-257. [CrossRef]

56. Lee, W.G.; Kim, D.H.; Jeon, W.C.; Kwak, S.K.; Kang, S.J.; Kang, S.W. Facile control of nanoporosity in Cellulose Acetate using Nickel(II) nitrate additive and water pressure treatment for highly efficient battery gel separators. Sci. Rep. 2017, 7, 1-9. [CrossRef] [PubMed]

57. Liu, L.; Gong, D.; Bratasz, L.; Zhu, Z.; Wang, C. Degradation markers and plasticizer loss of cellulose acetate films during ageing. Polym. Degrad. Stab. 2019, 168, 108952. [CrossRef]

58. Pan, H.B.; Li, Z.Y.; Lam, W.M.; Wong, J.C.; Darvell, B.W.; Luk, K.D.K.; Lu, W.W. Solubility of strontium-substituted apatite by solid titration. Acta Biomater. 2009, 5, 1678-1685. [CrossRef]

59. Toprak, C.; Agar, J.N.; Falk, M. State of water in cellulose acetate membranes. J. Chem. Soc. Faraday Trans. 1 Phys. Chem. Condens. Phases 1979, 75, 803-815. [CrossRef]

60. Prekajski, M.; Mirković, M.; Todorović, B.; Matković, A.; Marinović-Cincović, M.; Luković, J.; Matović, B. Ouzo effect-new simple nanoemulsion method for synthesis of strontium hydroxyapatite nanospheres. J. Eur. Ceram. Soc. 2016, 36, 1293-1298. [CrossRef]

61. Berzina-Cimdina, L.; Borodajenko, N. Research of Calcium Phosphates Using Fourier Transform Infrared Spectroscopy. In Infrared Spectroscopy —Materials Science, Engineering and Technology; IntechOpen: London, UK, 2012.

62. Vishal Gupta, N.; Shivakumar, H.G. Investigation of swelling behavior and mechanical properties of a pH-sensitive superporous hydrogel composite. Iran. J. Pharm. Res. 2012, 11, 481-493. [CrossRef]

63. Lyu, S.P.; Untereker, D. Degradability of polymers for implantable biomedical devices. Int. J. Mol. Sci. 2009, 10, 4033-4065. [CrossRef]

64. Retzepi, M.; Donos, N. Guided bone regeneration: Biological principle and therapeutic applications. Clin. Oral Implant. Res. 2010, 21, 567-576. [CrossRef]

65. Al Hegy, A.; Smith, R.; Gauthier, E.R.; Gray-Munro, J.E. Investigation of a cyanine dye assay for the evaluation of the biocompatibility of magnesium alloys by direct and indirect methods. Bioact. Mater. 2020, 5, 26-33. [CrossRef]

66. Gonzalez, J.; Hou, R.Q.; Nidadavolu, E.P.S.; Willumeit-Römer, R.; Feyerabend, F. Magnesium degradation under physiological conditions-Best practice. Bioact. Mater. 2018, 3, 174-185. [CrossRef]

67. Tie, D.; Feyerabend, F.; Hort, N.; Willumeit, R.; Hoeche, D. XPS studies of magnesium surfaces after exposure to Dulbecco's modified eagle medium, Hank's buffered salt solution, and simulated body fluid. Adv. Eng. Mater. 2010, 12, 699-704. [CrossRef]

68. Souter, P.; Cunningham, J.C.; Horner, A.; Genever, P.G. The variable toxicity of silver ions in cell culture media. Toxicol. Vitr. 2019, 60, 154-159. [CrossRef]

69. Zuberek, M.; Wojciechowska, D.; Krzyzanowski, D.; Meczynska-Wielgosz, S.; Kruszewski, M.; Grzelak, A. Glucose availability determines silver nanoparticles toxicity in HepG2. J. Nanobiotechnol. 2015, 13, 1. [CrossRef] [PubMed]

70. Thevenot, P.; Hu, W.; Tang, L. Surface chemistry influences implant biocompatibility. Curr. Top. Med. Chem. 2008, 8, 270-280. [CrossRef] [PubMed]

71. Calciolari, E.; Akcall, A.; Donos, N. The Role of Osteopromotive Membranes in Guided Bone Regeneration. In Bone Augmentation by Anatomical Region: Techniques and Decision-Making; Artzi DMD, Z., Ed.; Wiley Online Library: Hoboken, NJ, USA, 2020; pp. 69-93. [CrossRef]

72. Ding, X.; Li, X.; Li, C.; Qi, M.; Zhang, Z.; Sun, X.; Wang, L.; Zhou, Y. Chitosan/dextran hydrogel constructs containing strontiumdoped hydroxyapatite with enhanced osteogenic potential in rat cranium. ACS Biomater. Sci. Eng. 2019, 5, 4574-4586. [CrossRef] [PubMed]

73. Sultana, N.; Zainal, A. Cellulose acetate electrospun nanofibrous membrane: Fabrication, characterization, drug loading and antibacterial properties. Bull. Mater. Sci. 2016, 39, 337-343. [CrossRef]

74. Robertson, R.M.; Thomas, W.C.; Suthar, J.N.; Brown, D.M. Accelerated degradation of cellulose acetate cigarette filters using controlled-release acid catalysis. Green Chem. 2012, 14, 2266-2272. [CrossRef] 
75. Ruggiero, R.; de Almeida Carvalho, V.; da Silva, L.G.; de Magalhães, D.; Ferreira, J.A.; de Menezes, H.H.M.; de Melo, P.G.; Naves, M.M. Study of in vitro degradation of cellulose acetate membranes modified and incorporated with tetracycline for use as an adjuvant in periodontal reconstitution. Ind. Crops Prod. 2015, 72, 2-6. [CrossRef]

76. Fiorilli, S.; Molino, G.; Pontremoli, C.; Iviglia, G.; Torre, E.; Cassinelli, C.; Morra, M.; Vitale-Brovarone, C. The incorporation of strontium to improve bone-regeneration ability of mesoporous bioactive glasses. Materials 2018, 11, 678. [CrossRef] 